\title{
Public Social Welfare System
}

\author{
Irina P. Vorobyeva* ${ }^{a}$, Tran Thi Hong Phuong ${ }^{b}$ \\ * Corresponding author: Irina P. Vorobyeva, vorobjevaip@mail.ru
}

${ }^{a}$ National Research Tomsk Polytechnic University, Russia, 634050, Tomsk, Lenin Avenue, 30, E-mail; vorobjevaip@mail.ru ${ }^{b}$ National Research Tomsk Polytechnic University, Russia, 634050, Tomsk, Lenin Avenue, 30 E-mail: hongphuongdhtn@gmail.com

\begin{abstract}
http://dx.doi.org/10.15405/epsbs.2017.01.93

The relevance of this study is determined by the fact that the economic welfare of the society depends not only on commercial but also public budget activities. Citizens with different income levels are interested in the stable public social safety net. It is important to understand the nature and efficiency of the public welfare system aimed at protecting social and economic welfare for different categories of citizens. The study uses the benchmark method to understand the key trends. The analytical method of research is used to understand the common problems of the public welfare system. In Russia, the public social safety net has been established in order to protect social and economic welfare of those citizens who are unable to do it themselves. This system includes legal, financial, and organizational components. The laws specify the categories of people who are eligible to receive aid from public authorities. The system provides for welfare payments in cash and social services to citizens. Payments in cash are sourced from budgets of different levels. Social institutions are divided into several groups depending on sources of funding. The pension and health care systems in Vietnam have in common with those in Russia. However, citizens in Vietnam are more involved in funding these systems. The accounting and public contracting system allows social organizations to use public funds in an efficient and targeted manner. There are some problems of funding the social sector in remote areas. These problems can be solved through differential funding.
\end{abstract}

(c) 2017 Published by Future Academy www.FutureAcademy.org.uk

Keywords: Public funding of the social sector, protected categories in Russia and Vietnam, funding of the social sector, accounting in social organizations.

\section{Introduction}

According to the Constitution of the Russian Federation (Article 7), Russia is a social state. This means that the economic and social welfare of citizens is the most important function of the State. Due to the versatility of the social policy, legislative and executive authorities use a systematic approach to 
implement it. The purpose of this article is to review the public welfare system funded from the state budget.

\section{Public Social Safety Net in Russia (Based on the Maternity and Childhood Protection)}

The social policy aimed at protecting the economic and social welfare of citizens has the following objectives:

- $\quad$ to define social guarantees for citizens as reflected in the Basic Law (Articles $37-44$ of the RF Constitution);

- to determine the principles of the social policy and social security, as well as mechanisms of their implementation;

- $\quad$ to identify the social groups who are particularly in need of social security;

- to legalize certain social guarantees defined in quantitative and quantitative terms for each group protected by the State.

- $\quad$ to establish executive bodies aimed at providing these socially vulnerable groups with social security, including payments in cash, payments in kind, and services.

Thus, the State guarantees the economic and social welfare on the basis of:

- legal (legislative) mechanism, development of laws that define the protected categories, principles and options of social security, funding sources, and responsible authorities;

- administrative and management mechanism, i. e. establishment and empowerment of respective executive bodies;

- financial mechanism, determination of funding sources, sizes and types of payments.

Let us illustrate this with an example: The Constitution of the Russian Federation sets forth the State's commitments for the protection of motherhood and childhood (Article 38). A number of laws and regulations have been adopted on the basis of this article. They reflect the guarantees given by the public authorities, define the social groups in this field, fixes types and amounts of payments.

Table 1. Laws and Regulations in the Field of Maternity and Childhood Protection

\begin{tabular}{ll}
\hline Law / regulation & Date, number \\
\hline On the State Benefits to Citizens with Children & N 81-FZ, of May 19, 1995 \\
$\begin{array}{l}\text { On the Social Security of Citizens } \\
\text { with Minor Children }\end{array}$ & Law of the Tomsk Region No. 253-OZ of December 16, 2004 \\
UN Convention on the Rights of the Child & $\begin{array}{l}\text { Adopted by the UN General Assembly on November 20, } \\
\text { 1989, ratified by the USSR on September 15, 1990. }\end{array}$ \\
\hline
\end{tabular}

These laws and regulations determine the basic categories of citizens to be protected (pregnant women, women in labour, mothers, children up to 1.5 years of age, pre-school and school-age children). Table 2 shows the basic payments and benefits for pregnant women and women in labor. 
Table 2. State Guarantees for Pregnant Women, Women in Labour, and Mothers (Russian newspaper, 2016)

\begin{tabular}{|c|c|c|}
\hline Type of benefit & Amount in 2016, roubles & Amount in 2015, roubles \\
\hline Maternity benefit $(140,156$, or 194 days $)$ & $\begin{array}{l}100 \% \text { of the average earnings for } \\
\text { two previous years or minimum } \\
\text { wage }\end{array}$ & $\begin{array}{l}100 \% \text { of the average earnings } \\
\text { for two previous years or } \\
\text { minimum wage }\end{array}$ \\
\hline $\begin{array}{l}\text { Lump-sum benefit to women who have } \\
\text { registered at a health care institution in the } \\
\text { early stages of pregnancy }\end{array}$ & 581.73 & 543.67 \\
\hline Lump-sum baby bonus & $15,512.65$ & $14,497.80$ \\
\hline $\begin{array}{l}\text { Lump-sum benefit to a pregnant wife of a } \\
\text { conscript }\end{array}$ & $24,565.89$ & $22,958.78$ \\
\hline Maternity capital & 453,026 & 453,026 \\
\hline \multirow[b]{2}{*}{$\begin{array}{l}\text { Minimum amount of the monthly childcare } \\
\text { benefit for children up to } 1.5 \text { years of age }\end{array}$} & $2,908.62$ (for the first child) & $2,718.34$ (for the first child) \\
\hline & $\begin{array}{l}5,817.24 \text { (for the second and } \\
\text { subsequent children) }\end{array}$ & $\begin{array}{l}5,436.67 \text { (for the second and } \\
\text { subsequent children) }\end{array}$ \\
\hline
\end{tabular}

As seen from Table 2, the amount of payments increases from year to year due to price increase. The State uses certain procedures for providing benefits, including recording of needy citizens and fulfillment of its commitments to the extent of the amounts set by the applicable laws. An interesting question is how the authorities fulfill their commitments and what are the financial resources they rely on. The Russian Federation has clearly defined the directions of social security for different categories of needy citizens. These are:

- $\quad$ social security benefits in cash (e.g., maternity benefits);

- lump-sum payments in cash (e.g., baby bonus);

- $\quad$ payments in kind (e.g., baby gift sets);

- permanent, systematic and occasional social security services (services of children's polyclinics, maternity homes, children's homes, etc.).

\section{Public Social Safety Net in Vietnam (Based on the Pension and Health Care Systems)}

Welfare of citizens is the key concern in many other countries, including Vietnam. Let us illustrate this by the example of the pension and health care systems.

The following persons are eligible to receive a pension in Vietnam:

- Citizens who have reached the normal retirement age: 60 years for men and 55 years for women.

- Men in the age of 55-60 years and women in the age of 50-55 years are eligible for a pension if they have worked at least 15 years in heavy, hazardous and dangerous occupations.

- Coal miners in the age of 50-55 years are eligible for a pension if they have paid social insurance contributions for at least 20 years.

- HIV/AIDS infected individuals, employees who become disabled as a result of a work-related accident.

The retirement pension is equal to $45 \%$ of average earnings and paid for the first 15 years of social insurance contributions, plus 2\% (men) or 3\% (women) for each year of contributions exceeding 15 years. The maximum pension is $75 \%$ of average earnings. The Pension Fund in Vietnam is based on the 
social insurance system. Contributions include $8 \%$ of earnings paid by employees and $18 \%$ paid by employers (Law on Social Insurance of Vietnam Government, 2015).

As for the health care, it should be noted that in recent years the level of medicine has been significantly increased in Vietnam.

The health care system in Vietnam incorporates Western and Oriental medicine. The traditional (oriental) medicine is aimed at disease prevention and treating some chronic diseases and diseases at an early stage. Herbal medicine, acupuncture and manual therapy are widely used.

In Vietnam, there are four large state recognized centers of traditional medicine (two in Hanoi and two in Ho Chi Minh City), as well as over 9,000 small private clinics and practitioners across the country. There are ten international hospitals.

The Franco-Vietnamese Hospital and Cho Ray Hospital in Ho Chi Minh City get the best reviews for their level of medical care.

In addition to public hospitals, there are 66 private hospitals and 45 thousand private clinics in Vietnam. In recent years, increasingly more Chinese clinics have been established in the country (Medicine in Vietnam, 2016).

There are two forms of insurance policies in Vietnam: compulsory and voluntary (Table 3 ).

Table 3 Health Insurance in Vietnam (Nộidungcơbảncủabảohiểm y tế ở ViệtNam, 2016)

\begin{tabular}{llll}
\hline Year & $\begin{array}{l}\text { Numbers of persons covered by } \\
\text { social insurance programs }\end{array}$ & $\begin{array}{l}\text { Numbers of persons with } \\
\text { compulsory health insurance } \\
\text { policy }\end{array}$ & $\begin{array}{l}\text { Numbers of persons with voluntary } \\
\text { health insurance policy }\end{array}$ \\
\hline 2007 & $7,248,000$ & $(\approx 70,000)$ & $\approx 100,000$ \\
2012 & $10,437,000$ & 89,612 & 140,000 \\
\hline
\end{tabular}

The compulsory health insurance is available for employees and officials working in state-owned enterprises, administrative offices of the Party, in political and social institutions.

The voluntary health insurance system covers both Vietnamese citizens and foreigners.

Health insurance policy holders are eligible for a wide range of services, including health check-ups, treatment, tests, pharmacological support, etc. $80 \%$ of health care costs are paid by the health insurance fund; $20 \%$ are paid by individuals themselves.

Persons with compulsory health insurance contribute $3 \%$ of their earnings.

Thus, the social welfare of Vietnamese citizens is largely provided by the social insurance system.

\section{Financial Mechanism of the Social Welfare System in Russia}

The social welfare system is supported by several financial flows:

1. Funding of payments in cash and budget expenditures for the bodies through which the State fulfills its financial commitments (in case of the maternity capital, this is the RF Pension Fund).

2. Funding of non-cash benefits and transfer of lost revenues to responsible bodies. First of all, it includes subsidies for utility bills paid to providers of heat, water, etc. 
3. The funding of the social sector, which is responsible for ensuring an adequate standard of living for those who need the government support.

Sources of funding include state budgets of different levels, and budgets of state extra-budgetary funds. Social security is implemented as follows:

1. Payments in cash are mainly funded from extra-budgetary funds, such as the Pension Fund and the Social Insurance Fund of the Russian Federation.

2. The social sector, including non-cash benefits, is funded from the budget system of the Russian Federation. Funding of social organizations is distributed between the budgets depending on their importance and powers of the respective authorities.

In recent years, much effort has been put to systematize the existing benefits. Thus, the number of benefits has been optimized, privileged categories were assigned to a specific budget level (e.g., benefits for the 1st, 2nd and 3rd disability groups are funded from the Federal Budget, while benefits for veterans of labour - from regional budgets). In 2014, the share of expenditure on social and cultural activities reached $32.2 \%$ of the Federal Budget and $62.8 \%$ of regional budgets (Russian Statistical Yearbook, 2015).

The social sector has various functions. First of all, the social sector includes organizations aimed at solving problems of needy citizens in the field of health care, education, social services, income support, etc. The broad interpretation of the social sector implies that it includes organizations ensuring a decent standard of living (in addition to the above-listed ones, these are organizations in the field of cultural, sports, transport, communications, and recreation, etc). The State is not able to finance all these areas. This is why the social sector can be divided into the following categories depending on a source of funding:

1. Organizations funded by the State to ensure a decent standard of living for those who physically cannot have income (nursing homes for senior and disabled persons, children's homes, homeless shelters, points of temporary stay, etc.).

2. Organizations funded from budgets to provide affordable services to citizens, especially in the field of education and health care.

3. Organizations operating on a co-funding basis. Public funding ensures that services are affordable to consumers who pay only a part of their cost. These are kindergartens, paid cultural and sports clubs, some museums, etc.

4. Commercial services in the field of health care, education, tourism, recreation, sports, etc. These organizations operate on a self-funding basis and provide paid services. A range of commercial social services is gradually expanding. At the present, there are 302 public and 107 private kindergartens in Tomsk.

Funding and co-funding of the social sector are aimed at ensuring the intended use of public funds and providing high-quality services. In case of self-funding, organizations are required to comply with national standards for their services and to have a license for educational or health care activities. 


\section{Accounting of Financial Flows in the Social Sector}

The funding of the social sector should be based on publicity, transparency, effective and intended expenditures. The purpose of budgetary accounting in organizations of the social sector is to bring these principles to life. The recent changes in the budgetary accounting pursue the same purpose. The accounting policy of government-funded, government-owned and autonomous organizations is based on the respective orders of the Ministry of Finance Table 4).

Table 4. Laws and Regulation in the Field of Budgetary Accounting

\begin{tabular}{|c|c|c|}
\hline Law / regulation & Date, number & Purpose \\
\hline $\begin{array}{l}\text { On the Amendments to Some Legislative Acts in } \\
\text { Connection with the Improvement of the Legal Status of } \\
\text { Public / Municipal Organizations. }\end{array}$ & $\begin{array}{l}\text { Federal Law FZ-83 of April } \\
23,2010\end{array}$ & $\begin{array}{l}\text { Division of organizations } \\
\text { into government-owned, } \\
\text { government-funded, and } \\
\text { autonomous ones. }\end{array}$ \\
\hline $\begin{array}{l}\text { On the Approval of the Chart of Budget Accounts and the } \\
\text { Instruction for Use }\end{array}$ & $\begin{array}{l}\text { Order of the RF Ministry of } \\
\text { Finance No. 162n of December } \\
06,2010\end{array}$ & $\begin{array}{l}\text { Instructions for budgetary } \\
\text { accounting in government- } \\
\text { owned organizations }\end{array}$ \\
\hline $\begin{array}{l}\text { On the Approval of the Chart of Accounts in } \\
\text { Government-Funded Organizations and the Instruction } \\
\text { for Use }\end{array}$ & $\begin{array}{l}\text { Order of the RF Ministry of } \\
\text { Finance No. 174n of December } \\
16,2010\end{array}$ & $\begin{array}{l}\text { Instructions for accounting } \\
\text { in government-funded } \\
\text { organizations }\end{array}$ \\
\hline $\begin{array}{l}\text { On the Approval of the Chart of Accounts in } \\
\text { Autonomous Organizations and the Instruction for Use }\end{array}$ & $\begin{array}{l}\text { Order of the RF Ministry of } \\
\text { Finance No. } 183 \mathrm{n} \text { of December } \\
23,2010\end{array}$ & $\begin{array}{l}\text { Instructions for accounting } \\
\text { in autonomous } \\
\text { organizations }\end{array}$ \\
\hline
\end{tabular}

The budgetary accounting is based on the following principles:

1. Uniform accounting for different organizations of the social sector. The Uniform Chart of Accounts (Instruction 157n) applies to all organizations that receive budgetary subsidies for executing government / municipal orders in the social sector, or operating on the basis of a budget estimate. These organizations use the Uniform Chart of Accounts even if they are engaged in commercial activities. The Uniform Chart of Accounts is highly flexible and designed for accounting of transactions in various areas.

2. The budgetary accounting is based on codes of budget accounts. The main codes are presented in Table 5. The purpose of these codes (Codes of the Public Sector Transactions) is to ensure the intended use of budgetary funds.

Table 5. Codes of the Public Sector Transactions

\begin{tabular}{ll}
\hline Budget account & Code of the Public Sector \\
& Transactions \\
\hline Remuneration of labour & 211 \\
Taxes and charges on labour remuneration & 213 \\
Communication services & 221 \\
Transport services & 222 \\
Utility services & 223 \\
Rental of premises & 224 \\
Property maintenance services & 225 \\
Other services & 226 \\
Pensions, benefits and payments within the framework of pension, social and health & 261 \\
\hline
\end{tabular}




\begin{tabular}{ll}
\hline insurance of citizens & 262 \\
Social security benefits & 310 \\
Increase in value of fixed assets & 340 \\
Increase in value of inventories & \\
\hline
\end{tabular}

Due to these codes included in some accounts $(30405,30404,40120,40110)$, auditors can trace cash execution of a budget in targeted areas, fulfillment of commitments, and actual expenditure of organization's assets. For example, account 30405310 (settlement of budgetary payments) shows that an organization has settled with suppliers for purchased fixed assets. .

3. Itemization A budget account has 26 digits. They show type of a budget, administrator's code, type of activity, item (asset, liability, financial result), accounts and subaccounts, movement in an account. This itemization allows auditors to trace a business transaction by area of funding. This is the advantage of budget accounting over the commercial chart of accounts. Some examples are demonstrated in Table 6.

Table 6 Examples of Records in Budgetary and Commercial Accounting (Vorobyeva et al.,2013)

\begin{tabular}{|c|c|c|c|}
\hline Transaction & $\begin{array}{l}\text { Record of a business } \\
\text { transaction in commercial } \\
\text { accounting }\end{array}$ & $\begin{array}{l}\text { Record of a business } \\
\text { transaction in budgetary } \\
\text { accounting }\end{array}$ & $\begin{array}{l}\text { Advantages of budgetary } \\
\text { accounting }\end{array}$ \\
\hline Purchase of medicines & $\begin{array}{l}\text { DT (debit) } 10-\mathrm{KT} \text { (credit) } \\
60\end{array}$ & $\begin{array}{l}\text { DT (debit) 10531340- } \\
\text { - KT (credit) } 30234730\end{array}$ & $\begin{array}{l}\text { The accounts show that } \\
\text { some materials have been } \\
\text { purchased ( } 340)\end{array}$ \\
\hline Purchase of food products & $\begin{array}{l}\text { DT (debit) } 10-\mathrm{KT} \text { (credit) } \\
60\end{array}$ & $\begin{array}{l}\text { DT (debit) } 10532340- \\
\text { - KT (credit) } 30234730\end{array}$ & $\begin{array}{l}\text { The account of materials } \\
(105) \text { is itemized by type } \\
(31-\text { medicines, } 32-\text { food } \\
\text { products) }\end{array}$ \\
\hline $\begin{array}{l}\text { Settlements with suppliers } \\
\text { of medicines and food } \\
\text { products }\end{array}$ & $\begin{array}{l}\text { DT (debit) } 60-\mathrm{KT} \text { (credit) } \\
51\end{array}$ & $\begin{array}{l}\text { DT (debit) } 30234830- \\
\text { - KT (credit) } 30405340\end{array}$ & $\begin{array}{l}\text { This account allows auditors } \\
\text { to trace how funds are } \\
\text { expended (purchase of } \\
\text { materials). }\end{array}$ \\
\hline
\end{tabular}

Thus, the new instructions for budgetary accounting have significantly simplified the audit system for organizations of the social sector as related to use of public / municipal budgetary funds allocated for social support of citizens, their economic and social welfare. At the same time, some problems associated with the provision of social services to recipients have not been solved or even have been aggravated. These problems include.

1. Due to the fact that some organizations, especially in the periphery of the country, deal with a limited range of citizens who need their services, budgetary subsidies for execution of government / municipal orders do not ensure the normal existence of these organizations. These government-funded and autonomous organizations were switched over to budgetary subsidies in order to get them interested in increasing amount of their services. For example, the more children are in a school, the more patients are in a hospital, the more readers are in a library, etc., the higher will be budgetary subsidies. As a result, small schools, medical stations, clubs, and libraries in remote villages are under threat of closure. The formal transfer of government-funded institutions from cost estimates to budget subsidies allocated in 
proportion to amount of provided services have caused severe damage to sparsely populated areas of Russia.

2. One of the objectives of the fiscal reform in the social sector was to ensure the efficient use of budgetary funds. If the organization operates on the basis of cost estimates, it will spend all allocated funds, even if there is no special need to do this. Managers of these organizations are interested that a sum of their estimates does not decrease. It was hoped that governmentfunded and autonomous organizations would be more efficient in using public funds. However, these expectations have not been met. Organizations even do not disclose excess cash in their budget reports and still try to use them up to the end of a reporting period.

3. The bureaucratic contracting system used in connection with the adoption of the Law 44-FZ, does not allow organizations to quickly solve everyday tasks. Organizations have increased their staff by hiring specialists in public procurement. A number of contracts with advance payments have decreased. As a result, recipients of social services sometimes have to wait for something they urgently need (e.g., medicines, exercise equipment, prostheses, etc.).

4. In their effort to meet the requirements of budgetary accounting and the Law 44-FZ, organizations often consider the quality of social services as something secondary. The main thing for a head of a social organization is not to exceed a cost estimate or budget subsidy, as well as to fulfil the applicable contracting regulations.

We would recommend the following measures:

1. To introduce a rating system for assessing the organization's activities, including feedback from recipients of social services.

2. To tie a cost estimate / subsidy to performance of an organization and to differentiate funding depending on quality of its services.

3. The problems of funding the social sector in sparsely populated areas have been often solved by consolidating and uniting organizations. As a result, their services are less affordable and of a lower quality than before. In some regions, schools and medical institutions change their status to a government-owned organization to solve their funding problems. In our opinion, an amount of subsidies for sparsely populated areas can be changed by introducing an adjustment factor.

\section{Conclusion}

Thus, the public social safety net has been established in Russia in order to protect social and economic welfare of those citizens who are unable to do it themselves. This system includes legal, financial, and organizational components. In addition, the accounting and public contracting system allows social organizations to use public funds in an efficient and targeted manner. Certainly, these systems have some weaknesses, but all of these problems can be solved. The system has proved to be viable. 
http://dx.doi.org/10.15405/epsbs.2017.01.93

eISSN: 2357-1330 / Corresponding Author: Irina P. Vorobyeva

Selection and peer-review under responsibility of the Organizing Committee of the conference

\section{References}

Consolidated Budget of the Russian Federation and Budgets of the State Extra-budgetary Funds in 2014. Russian Statistical Yearbook. (2015).Moscow. Rosstat.

Law on Social Insurance of Vietnam Government N 63. (2016, April 10). Retrieved from http://moj.gov.vn/vbpq/en/lists/vn\%20bn\%20php\%20lut/view detail.aspx?itemid $=4751$

Medicine in Vietnam. (2016, April 16). Retrieved from http://vietnamnet.ru/med

Nộidungcơbảncủabảohiểm y tế ở ViệtNam. (2016, April 10). Retrieved from http://voer.edu.vn/m/noi-dung-co-ban-cua-baohiem-y-te-o-viet-nam/0698b206.

On Setting the Indexation Rate of Payments, Benefits, and Compensations. (2016, January 28). Russian newspaper. Retrieved from https://rg.ru

Vorobyeva, I.P., Spesivtseva A.L., Barysheva G.A. (2013). Accounting in Government-Funded Organizations. Tomsk. Tomsk Polytechnic University. 